\title{
Sexual Maturation, social support and physical activity in adolescents
}

\section{Maduración sexual, apoyo social y actividad física en adolescentes}

\section{Maturação sexual, apoio social e atividade física em adolescentes}

\author{
Piola, T.S. ${ }^{1}$, Bacil, E.D.A. ${ }^{1,2}$, Watanabe, P.I. ${ }^{1}$, Camargo, E.M. ${ }^{1,4}$, Fermino, R. ${ }^{3,4}$, Campos, W' ${ }^{1}$.
}

${ }^{1}$ Center for Physical Activity and Health Studies. Federal University of Paraná. Physical Education Department. Post-Graduation Program in Physical Education. Curitiba-PR, Brazil, ${ }^{2}$ Positive University. Curitiba-PR, Brazil; ${ }^{3}$ Research Group on Environment, Physical Activity and Health. Federal Technological University of Paraná. Academic Department of Physical Education. Post-Graduation Program in Physical Education. Curitiba-PR, Brazil, ${ }^{4}$ Research Group on Physical Activity and Quality of Life. Pontifical Catholic University of Paraná. School of Life Science. Curitiba-PR, Brazil.

\begin{abstract}
To analyze moderating maturation effect on association between social support and physical activity level in adolescents. Cross-sectional study conducted in 2014 with a representative sample of 855 adolescents (54\% girls) enrolled in public school of São José dos Pinhais, Brazil. Adolescents reported weekly attendance who received different types of social support for physical activity, which was classified into three categories ("never," "sometimes," "always"). The social support score from each source was computed and classified in tertiles ("low", "intermediate", "high"). The moderate to vigorous leisure time physical activity was evaluated with a valid questionnaire and the score was classified as $\geq 300 \mathrm{~min} / \mathrm{wk}$. The maturation was self-assessed by pubic hairiness by photos and classified as "pubescent" and "post-pubescent". The associations were tested with Poisson regression in STATA 14. The fact that parents "sometimes" (PR: 2.51; 95\% CI: 1.42-4.44) or "always" (PR: 4.60; 95\% CI: 2.10 10.10) to attend the activities was positively associated with the physical activity of pubertal adolescents, whereas positive reinforcement for the activities ("always" commenting) was positively associated with the outcome in postpubertal adolescents (PR: 2.60; 95\% CI: 1.01-6.71). The fact that friends "always" watch activities (PR: 2.39; 95\% CI: 1.01-5.76), the score "intermediate" (PR: 2.13; 95\% CI: 1.28-3.58) and "high" (RP: 1.91; 95\% CI: 1.11-3.28) were positively associated with the physical activity of pubertal adolescents. Maturation shows a moderating effect in the association between the social support and physical activity.
\end{abstract}

Keywords: Social Support; Motor Activity; Puberty; Adolescent; Epidemiologic Studies.

\section{RESUMEN}

Analizar el efecto moderador del desarrollo y su asociación con el apoyo social, recibido de padres y de amigos, y en el nivel de actividad física de adolescentes. Estudio transversal con una muestra representativa de 855 adolescentes (54\% mujeres), de São José dos Pinhais-PR. Los adolescentes reportaron la frecuencia semanal de diferentes tipos de apoyo social recibido para realizar actividad física, el cual fue clasificado en tres categorías ("nunca", "a veces", "siempre"). También fue computado un puntaje de apoyo social, proveniente de cada fuente y clasificado en tres 


\section{Piola, T.S., Bacil, E.D.A., Watanabe, P.I., Camargo, E.M., Fermino, R., Campos, W.}

categorías ("bajo", "intermedio", "alto"). La actividad física moderada a vigorosa en tiempo libre, fue evaluada con un cuestionario y clasificado con un puntaje de $\geq 300 \mathrm{~min} / \mathrm{sem}$. La etapa de desarrolho, fue autoevaluada por el participantes con ayuda de fotos de adolescentes clasificados en "púberes" y "pos-púberes". Las asociaciones fueron probadas con regresiones de Poisson no STATA 12. La prevalencia de actividad física fue de 21,6\%. Se presentó apoyo de los padres "a veces" (RP: 2,51; IC95\%: 1,42-4,44) y "siempre" (RP: 4,60; IC95\%: 2,10-10,10) en las actividades y fue positivamente asociado con la actividad física de los adolescentes y púberes. Existe un refuerzo positivo para realizar las actividades si ("siempre") hay apoyo y fue positivamente asociado al desenlace de los adolescentes pos-púberes (RP: 2,60; IC95\%: 1,01-6,71). Si los amigos "siempre" asisten a las actividades (RP: 2,39; IC95\%: 1,01-5,76), o un puntaje "intermedio" (RP: 2,13; IC95\%: 1,28-3,58) y "elevado" (RP: 1,91; IC95\%: 1,113,28 ) de apoyo de las actividades fueron positivamente asociados con la actividad física de los adolescentes púberes. El desarrollo tuvo un efecto moderador en la asociación entre el apoyo social y la actividad física.

Palabras clave: Apoyo Social; Actividad Motora; Pubertad; Adolescente; Estúdios Epidemiológicos.

\section{RESUMO}

Analisar o efeito moderador da maturação na associação entre o apoio social, recebido dos pais e dos amigos, no nível de atividade física de adolescentes. Estudo transversal realizado em $2014 \mathrm{com}$ amostra representativa de 855 adolescentes (54\% meninas) da rede pública de ensino de São José dos Pinhais-PR. Os adolescentes reportaram a frequência semanal que receberam diferentes tipos de apoio social para a atividade física, o qual foi classificado em três categorias ("nunca", "às vezes", "sempre"). Também foi computado o escore de apoio social, proveniente de cada fonte, e classificado em tercis ("baixo", "intermediário", "elevado"). A atividade física moderada a vigorosa no lazer foi avaliada com questionário válido e o escore classificado em $\geq 300 \mathrm{~min} / \mathrm{sem}$. A maturação foi autoavaliado pela pilosidade púbica por fotos e classificada em "púberes" e "pós-púberes". As associações foram testadas com a regressão de Poisson no STATA 14. O fato dos pais "as vezes" (RP: 2,51; IC95\%: 1,42-4,44) ou "sempre" (RP: 4,60; IC95\%: 2,10-10,10) assistirem as atividades foi positivamente associado com a atividade física dos adolescentes púberes. Enquanto o reforço positivo para as atividades ("sempre" comentarem) foi positivamente associado ao desfecho em adolescentes pós-púberes (RP: 2,60; IC95\%: 1,01-6,71). O fato dos amigos "sempre" assistirem as atividades (RP: 2,39; IC95\%: 1,01-5,76), o escore "intermediário" (RP: 2,13; IC95\%: 1,28-3,58) e "elevado" (RP: 1,91; IC95\%: 1,11-3,28) de apoio deles foram positivamente associados com a atividade física dos adolescentes púberes. A maturação apresenta efeito moderador na associação entre o apoio social e a atividade física.

Palavras chave: Apoio social; Atividade Motora; Puberdade; Adolescente; Estudos Epidemiológicos.

\section{INTRODUCTION}

Overall estimates indicate that physical inactivity in adolescence is high, and about $80 \%$ of adolescents do not reach the minimum recommendations of physical activity for health (Sallis et al., 2016), data similar to those found in the Brazil (Ferreira et al., 2018). Evidence from longitudinal studies indicates that the level of physical activity reduces in adolescence (Dumith, Gigante, Domingues, \& Kohl III, 2011). However, this decline seems to be associated with biological maturation (Sherar, Cumming, Eisenmann, Baxter-Jones, \& Malina, 2010), since the literature indicates a larger decrease in early maturing adolescents (Bacil, Mazzardo Junior, Rech, Legnani, \& Campos, 2015).

In fact, adolescence is marked by a set of physical, hormonal, psychological and behavioral changes, among others, which have some influence on the involvement in physical and sports activities, differently between the sexes (Bacil et al., 2015; Seabra, Mendonca, Thomis, Anjos, \& Maia, 2008). For girls, the pubertal development is inversely associated with psychological well-being and selfesteem which, in turn, may negatively impact on the involvement and sensation of pleasure related to physical activities (Davison, Werder, Trost, Baker, \& Birch, 2007). In boys, on the other hand, physical changes associated with maturation, such as increased height and muscle mass, result in a physical size adequate for success in sports activities (Bacil et al., 2015).

A number of individual, interpersonal, and environmental factors are associated with physical activity in adolescence, including social support 


\section{Sexual Maturation, social support and physical activity}

(Bauman et al., 2012; Sallis et al., 2016; Van Der Horst, Paw, Twisk, \& Van Mechelen, 2007). Conceptually, social support can be understood as aid or care received through interpersonal relationships, which is one of the most important functions of social relations (Glanz, Rimer, \& Viswanath, 2008). In addition to the influence that maturation exerts on physical and psychological changes related to physical activity, evidences point to alterations in intrapersonal and interpersonal relationships (Sherar et al., 2009). Recent reviews have identified a consistent positive association between different types and sources of social support and physical activity in adolescents (Beets, Cardinal, \& Alderman, 2010; Laird, Fawkner, Kelly, McNamee, \& Niven, 2016; G. Mendonça, Cheng, Melo, \& Farias Junior, 2014), without, however, considering the effect of maturation on most evidence.

The literature indicates differences in social support for the physical activity received by parents in relation to gender, adiposity and body composition, as well as in the strength of association that the types and sources of this support may represent in physical activity (Beets et al., 2010; Piola, Bacil, Silva, Pacifico, \& Campos, 2018; Prado, Lima, Fermino, Anez, \& Reis, 2014). For example, the company of friends has a greater magnitude of effect for boys, while the family company is more strongly associated with physical activity in girls (Prado et al., 2014). Since maturation influences different characteristics, it is believed that it may moderate the effect of the association between social support and physical activity (Bacil et al., 2015; Jackson et al., 2013; Sherar et al., 2010; Sherar et al., 2009).

No studies were found that analyzed the moderating effect of maturation on the association among these variables in adolescents of both sexes, and this analysis may be applied by the moderator effect, which could verify if sexual maturation affect the direction and/or strength of the relationship of social support and physical activity.

Understanding how maturation modifies the association between social support and physical activity may contribute to the design of effective interventions to increase levels of physical activity in adolescents (Sherar et al., 2010). Thus, the objective of this study was to analyze the moderating effect of maturation on the association between the social support received from parents and friends in the level of physical activity in adolescents.

\section{MATERIAL AND METHODS}

\section{Study design}

A cross-sectional and observational study was carried out in 2014, with a representative sample of adolescents enrolled in schools in the urban area, with high school, of the state education network of São José dos Pinhais, Paraná ( $\mathrm{n}=29$ schools, 10,523 students) (SEED-PR, 2014). The municipality is located in the metropolitan region $15 \mathrm{~km}$ from the capital (Curitiba), is the sixth largest in the state, medium size, has an area of $946 \mathrm{~km} 2$ (80\% rural), population of 302,759 inhabitants, population density of $310 \mathrm{hab} / \mathrm{km} 2$ and has a high Human Development Index (HDI - 0.758).

\section{Participants}

For the estimation of the sample calculation (Luiz \& Magnanini, 2000), an error of 5\% was considered, an estimated prevalence of insufficiently active of $51 \%$ (Barbosa Filho, Campos, Bozza, \& Lopes, 2012), a delineation effect of 1.4 applied on following equation;

$$
n=\frac{z_{\alpha / 2}^{2} \times N P(1-P)}{\varepsilon^{2}(N-1)+z_{\alpha / 2}^{2} \times P \times(1-P)}
$$

Additionally an increase of $30 \%$ for possible losses and refusals and a $95 \%$ confidence interval. Thus, the minimum sample required was estimated in 675 adolescents.

The sample was selected in three stages. In the first, all the schools that offered high school in the morning period were selected $(n=18)$. Following this, a simple random selection of one class from each high school series was performed according to the number of schoolchildren, proportional by sex, required by school. Finally, all students in each class were invited to participate in the study. Those excluded were schoolchildren under the age of 14 or older than 18 years and those with physical or cognitive limitations that limited the practice of physical activities. Adolescents who did not present the informed consent form signed by parents or guardians, those who refused to participate in the study or who missed 


\section{Piola, T.S., Bacil, E.D.A., Watanabe, P.I., Camargo, E.M., Fermino, R., Campos, W.}

classes on the day of collection were considered as losses. A total of 959 adolescents were evaluated; however, participants classified in the pre-pubertal maturational stage $(n=68)$ were excluded from the study, who completed the questionnaires with unlikely, incomplete or blank responses $(\mathrm{n}=36)$. Thus, the analytical sample was 855 adolescents.

A posteriori analysis showed that the sample $(n=855)$ could detect significant prevalence ratios (PR) above 1.22 as risk and below 0.80 as protection, with a power of $80 \%(\beta=20 \%), 95 \%$ confidence level $(\alpha=5 \%)$ and an insufficiently active prevalence of $78.4 \%$, calculated on software GPower 3.1.9.4.

\section{Data collection and ethical aspects}

The data were collected with the application of the standardized questionnaire in a coordinated way in the classroom, by previously trained evaluators. The study followed the research guidelines involving human beings of the National Health Council (resolution $\mathrm{n}^{\circ} 466 / 2012$ ) and investigation was performed according to the Helsinki declaration. The study was approved by the Research Ethics Committee of the Federal University of Paraná (CAAE: 36759414.0.0000.0102), and the parents / responsible signed the free and informed consent form.

\section{Instruments}

Social support for the practice of physical activities was evaluated with a validated questionnaire for Brazilian adolescents (Farias Júnior et al., 2011). The questionnaire presents six different types of social support, coming from two different sources, parents and friends. The types of social support received from the parents were: "stimulated", "practiced together", "led", "attended", "commented" and "talked" (table 1). In relation to friends, the following types of support were evaluated: "stimulated", "practiced together", "invited", "attended", "commented" and "talked" (table 1). Response options were set out on a fourpoint Likert scale, and adolescents reported weekly frequency ("never", "rarely", "often", "always") with which parents and friends provided some form of assistance and / or assistance (social support) to perform physical activities during a typical week.

For the purposes of analysis, and in order to ensure comparability with similar studies (Piola et al., 2018;
Prado et al., 2014), the "rarely" and "often" response options were grouped and classified as "sometimes". Thus, the weekly social support categories were classified as "never", "sometimes" and "always".

We chose to create a variable that represents the social support score received from each source, based on the sum of the six types of support received from parents and friends. Thus, the "general social support score" was classified into three levels according to tertiles: "low" (1st tertile), "intermediate" (2nd tertile) and "high" (3rd tertile).

The practice of physical activity in leisure was evaluated by completing the "Self-Administered Physical Activity Checklist", in its version adapted and validated for Brazilian adolescents (Farias Júnior et al., 2012). The adolescents reported weekly frequency and duration of participation in 22 types of physical activities, with moderate to vigorous intensities, in the last week.

The physical activity score was calculated with the sum of the product of the weekly frequency by the volume, in minutes, spent on each activity. The "walking on the move" and "walking with the dog" activities were excluded from the score because they were of mild intensity (Adams, Johnson, \& TudorLocke, 2013). A cut-off point of $\geq 300 \mathrm{~min} /$ week was used to classify adolescents as "physically active" (World Health Organization, 2010).

The maturation was autoevaluated by pubic hairiness by photos, using the Tanner method (Hills \& Byrne, 2010; Malina, Rogol, Cumming, Silva, \& Figueiredo, 2015). The stages vary from one to five, in the first the adolescent is considered as "pre-puberty" (pre-adolescence), in stages two, three and four are classified as "pubescent"; and stage five, as "postpuberty", which indicates that the maturational process is concluded (Lloyd, Oliver, Faigenbaum, Myer, \& Croix, 2014; Malina et al., 2015). However, for the present study, adolescents classified in stage one were excluded from the analysis $(n=68)$ because they characterized a phase of pre-adolescence (Malina et al., 2015).

In the review of the literature, some variables potentially associated with social support or level of physical activity were identified: sex, age, nutritional status and socioeconomic status (Bauman et al., 2012; 


\section{Sexual Maturation, social support and physical activity}

Sallis et al., 2016; Van Der Horst et al., 2007). These variables were selected, evaluated and tested as possible confounding factors. Gender was selfreported ("male", "female"), age classified in two age groups ("14-15 years", "16-17 years"), nutritional status (body mass index) measured body mass and height $(\mathrm{kg} / \mathrm{height})$ and adolescents classified as "normal weight" and "overweight" (Conde \& Monteiro, 2006). The socioeconomic status was evaluated with the standardized questionnaire based on the number of household utensils in the residence, presence of a monthly employee, and the school attendance of the household financial officer (ABEP, 2013). For the purpose of analysis, this variable was classified into three categories: "low" (class C + D), "intermediate" (class B1 + B2) and "high" (class A1 + A2).

\section{Statistical analysis}

Poisson regression was used to test the association between weekly frequency of different types of social support received from parents and friends and physical activity (Barros \& Hirakata, 2003). To test the possible moderating effect, maturation was included in the model ("puberty" versus "post-puberty") (Bauman, Sallis, Dzewaltowski, \& Owen, 2002). After the bivariate analysis, the multivariate model was elaborated considering as possible confounding factors the variables gender, age, nutritional status, socioeconomic status and other types of social support received from the same source (parents or friends). The variables entered the model at the same analysis level by the forced input method. Analyzes were performed on STATA 14 and the level of significance was maintained at $5 \%$.

\section{RESULTS}

The final sample consisted of 855 adolescents (54\% of girls), with a mean age of $16.1 \pm 1.1$ years. The highest proportion of adolescents were classified as pubertal maturational stage $(68.9 \%)$, were between $16-18$ years old $(50.6 \%)$, had normal nutritional status $(82.9 \%)$, intermediate socioeconomic status $(56.0 \%)$ and performed $<300 \mathrm{~min} /$ without moderate to vigorous leisure time physical activity (78.4\%) (table 1$)$. The male sex and the largest age group were positively associated with the post-pubertal maturational stage $(\mathrm{p} \leq 0.001)$.
The most common type of social support received from the parents was the encouragement of physical activity (22.0\%), while the least reported was physical activity with adolescents $(6.0 \%)$ (table 1). None of the types of social support received from parents was associated with the maturational stage. In relation to the support received from friends, the fact that they "practiced together" or "invited" to the activities was the most frequent $(23.0 \%)$, while the positive reinforcement ("commenting positively") was the least reported $(12.6 \%)$. The greatest stimulus, the company, the positive reinforcement, the fact that the friends attended and talked about the activities were positively associated with the post-pubertal maturational stage $(\mathrm{p} \leq 0.013)$ (table 1$)$.

In the bivariate analysis, in relation to the support received from parents, only the social support score showed no significant positive association with physical activity, regardless of the maturational stage. Among pubertal adolescents, the fact that parents "always" attended physical activities had the greatest strength of association with the outcome (PR: 5.44; 95\% CI: 3.12-9.47). Among post-pubertal adolescents, parental stimulation had the greatest positive association with physical activity (PR: 3.00; 95\% CI: 1.23-7.31). Each social support types received from friends were positively associated with the physical activity of pubescent adolescents. For post-pubertal adolescents, only the fact that friends "attended activities" and the social support score were not associated with physical activity (table 2 ).

After adjusting for the confounding variables (table 3 ), only the fact that the parents participated in the activities remained positively associated with the physical activity of pubescent adolescents ("sometimes"=PR: 2.51 ; 95\% CI:1.42) 4,44. For postpubertal adolescents, the fact that parents "always" comment positively on activities was positively associated with physical activity (PR:2.60; 95\% CI:1.01-6.10). In relation to friends, the fact that they always participated in activities (PR: 2.39; 95\% CI:1.01-5.76), as well as the highest support score ("intermediate"=PR: 2.13; 95\% CI:1.28-3.58 "high"=PR:1.91; 95\% CI:1.11-3.28), maintained a positive association with the physical activity of pubertal adolescents. 


\section{Piola, T.S., Bacil, E.D.A., Watanabe, P.I., Camargo, E.M., Fermino, R., Campos, W.}

Table 1. Descriptive characteristics of adolescents. by maturational stage. São José dos Pinhais, Paraná, Brazil, 2014 (n=855).

\begin{tabular}{|c|c|c|c|c|c|c|c|c|}
\hline \multirow[b]{3}{*}{ Variables } & \multirow[b]{3}{*}{ Category } & \multicolumn{4}{|c|}{ Maturational stage } & \multirow{3}{*}{$\mathbf{p}$} & \multirow{2}{*}{\multicolumn{2}{|c|}{$\begin{array}{c}\text { Todos } \\
(n=855)\end{array}$}} \\
\hline & & \multicolumn{2}{|c|}{ Pubere } & \multicolumn{2}{|c|}{$\begin{array}{c}\text { Post- } \\
\text { pubere }\end{array}$} & & & \\
\hline & & $\mathbf{n}$ & $\%$ & n & $\%$ & & $\mathbf{n}$ & $\%$ \\
\hline \multicolumn{9}{|l|}{ Individual and sociodemographic } \\
\hline \multirow[t]{2}{*}{ Maturational Stage } & Púbere & 589 & 68.9 & -- & -- & & -- & -- \\
\hline & Pós-púbere & -- & & 266 & 31.1 & & -- & -- \\
\hline \multirow[t]{2}{*}{ Sex } & Male & 241 & 40.9 & 151 & 56.8 & $<0.001^{\mathrm{h}}$ & 392 & 45.8 \\
\hline & Female & 348 & 59.1 & 115 & 43.2 & & 463 & 54.2 \\
\hline \multirow[t]{2}{*}{ Age } & $14-15$ & 314 & 53.3 & 108 & 40.6 & $0.001^{h}$ & 422 & 49.4 \\
\hline & $16-18$ & 275 & 46.7 & 158 & 59.4 & & 433 & 50.6 \\
\hline \multirow[t]{2}{*}{ Nutritional Status } & $\begin{array}{l}\text { Normal } \\
\text { Weight }\end{array}$ & 490 & 83.2 & 219 & 82.3 & $0.757^{\mathrm{h}}$ & 709 & 82.9 \\
\hline & Overweight & 99 & 16.8 & 47 & 17.7 & & 146 & 17.1 \\
\hline \multirow[t]{3}{*}{ Socioeconomic Status } & Low & 80 & 13.6 & 29 & 10.9 & $0.132^{\mathrm{t}}$ & 109 & 12.8 \\
\hline & Intermediate & 333 & 56.5 & 145 & 54.7 & & 478 & 56.0 \\
\hline & High & 176 & 29.9 & 91 & 34.3 & & 267 & 31.2 \\
\hline \multirow[t]{3}{*}{ Moderate to vigorous physical activity at leisure } & 300 & 469 & 79.6 & 201 & 75.6 & $0.182^{\mathrm{h}}$ & 670 & 78.4 \\
\hline & $\mathrm{min} / \mathrm{sem}$ & & & & & & & \\
\hline & $\begin{array}{l}\geq \quad 300 \\
\mathrm{~min} / \mathrm{sem}\end{array}$ & 120 & 20.4 & 65 & 24.4 & & 185 & 21.6 \\
\hline \multicolumn{9}{|l|}{ Social support received from parents } \\
\hline \multirow[t]{3}{*}{ Encouraged you to practice physical activities } & Never & 74 & 12.6 & 41 & 15.4 & $0.399^{\mathrm{t}}$ & 115 & 13.5 \\
\hline & Sometimes & 383 & 65.1 & 168 & 63.2 & & 551 & 64.5 \\
\hline & Always & 131 & 22.3 & 57 & 21.4 & & 188 & 22.0 \\
\hline \multirow[t]{3}{*}{ They practiced physical activities with you } & Never & 251 & 42.7 & 125 & 47.0 & $0.067^{t}$ & 376 & 44.0 \\
\hline & Sometimes & 295 & 50.2 & 132 & 49.6 & & 427 & 50.0 \\
\hline & Always & 42 & 7.1 & 9 & 34 & & 51 & 6.0 \\
\hline \multirow[t]{3}{*}{ They took you to practice physical activities } & Never & 234 & 39.8 & 106 & 39.8 & $0.540^{\mathrm{t}}$ & 340 & 39.8 \\
\hline & Sometimes & 248 & 42.2 & 103 & 38.7 & & 351 & 41.1 \\
\hline & Always & 106 & 18.0 & 57 & 21.4 & & 163 & 19.1 \\
\hline \multirow[t]{3}{*}{ Have watched you practice physical activities } & Never & 287 & 48.8 & 123 & 46.2 & $0.694^{\mathrm{t}}$ & 410 & 48.8 \\
\hline & Sometimes & 261 & 44.4 & 127 & 47.7 & & 388 & 45.4 \\
\hline & Always & 40 & 6.8 & 16 & 6.0 & & 56 & 6.6 \\
\hline \multirow{3}{*}{$\begin{array}{l}\text { They commented positively on their practice of } \\
\text { physical activities }\end{array}$} & Never & 245 & 41.7 & 110 & 41.4 & $0.379^{t}$ & 355 & 41.6 \\
\hline & Sometimes & 269 & 45.8 & 112 & 42.1 & & 381 & 44.7 \\
\hline & Always & 73 & 12.4 & 44 & 16.5 & & 117 & 13.7 \\
\hline \multirow[t]{3}{*}{ Talked to you about your physical activity } & Never & 199 & 33.8 & 94 & 35.3 & $0.906^{\mathrm{t}}$ & 293 & 34.3 \\
\hline & Sometimes & 304 & 51.7 & 128 & 48.1 & & 432 & 50.6 \\
\hline & Always & 85 & 14.5 & 44 & 16.5 & & 129 & 15.1 \\
\hline \multirow[t]{2}{*}{ General social support score received from parents } & Low & 209 & 35.5 & 93 & 35.0 & $0.443^{t}$ & 302 & 35.3 \\
\hline & Intermediate & 177 & 30.1 & 70 & 26.3 & & 247 & 28.9 \\
\hline
\end{tabular}

Cuadernos de Psicología del Deporte, 19, 3 (septiembre) 


\section{Sexual Maturation, social support and physical activity}

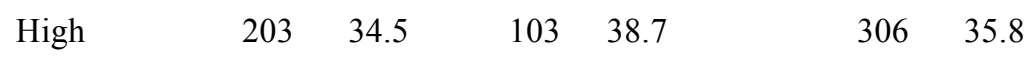

\begin{tabular}{|c|c|c|c|c|c|c|c|c|}
\hline \multirow[t]{3}{*}{$\begin{array}{l}\text { Soclal support recelvea from frlenas } \\
\text { Encouraged you to practice physical activities }\end{array}$} & Never & 199 & 33.8 & 71 & 26.7 & \multirow[t]{3}{*}{$0.004^{t}$} & 270 & 31.6 \\
\hline & Sometimes & 297 & 50.5 & 133 & 50.0 & & 430 & 50.4 \\
\hline & Always & 92 & 15.6 & 62 & 23.3 & & 154 & 18.0 \\
\hline \multirow[t]{3}{*}{ They practiced physical activities with you } & Never & 174 & 29.6 & 58 & 21.8 & \multirow[t]{3}{*}{$0.013^{t}$} & 232 & 27.2 \\
\hline & Sometimes & 288 & 49.0 & 137 & 51.5 & & 425 & 49.8 \\
\hline & Always & 126 & 21.4 & 71 & 26.7 & & 197 & 23.1 \\
\hline \multirow[t]{3}{*}{ They took you to practice physical activities } & Never & 135 & 23.0 & 52 & 19.5 & \multirow[t]{3}{*}{$0.058^{\mathrm{t}}$} & 187 & 21.9 \\
\hline & Sometimes & 329 & 56.0 & 142 & 53.4 & & 471 & 55.2 \\
\hline & Always & 124 & 21.1 & 72 & 27.1 & & 196 & 23.0 \\
\hline \multirow[t]{3}{*}{ Have watched you practice physical activities } & Never & 240 & 40.8 & 95 & 35.7 & \multirow[t]{3}{*}{$0.034^{t}$} & 335 & 39.2 \\
\hline & Sometimes & 279 & 47.4 & 125 & 47.0 & & 404 & 47.3 \\
\hline & Always & 69 & 11.7 & 46 & 17.3 & & 115 & 13.5 \\
\hline \multirow{3}{*}{$\begin{array}{l}\text { They commented positively on their practice of } \\
\text { physical activities }\end{array}$} & Never & 258 & 43.9 & 100 & 37.6 & \multirow[t]{3}{*}{$0.023^{t}$} & 358 & 41.9 \\
\hline & Sometimes & 265 & 45.1 & 123 & 46.2 & & 388 & 45.4 \\
\hline & Always & 65 & 11.1 & 43 & 16.2 & & 108 & 12.6 \\
\hline \multirow[t]{3}{*}{ Talked to you about your physical activity } & Never & 170 & 28.9 & 61 & 22.9 & \multirow[t]{3}{*}{$0.002^{t}$} & 231 & 27.0 \\
\hline & Sometimes & 318 & 54.1 & 135 & 50.8 & & 453 & 53.0 \\
\hline & Always & 100 & 17.0 & 70 & 26.3 & & 170 & 19.9 \\
\hline \multirow[t]{3}{*}{ General social support score received from friends } & Low & 180 & 30.6 & 90 & 33.8 & \multirow[t]{3}{*}{$0.652^{\mathrm{t}}$} & 270 & 31.6 \\
\hline & Intermediate & 214 & 36.3 & 72 & 27.1 & & 286 & 33.5 \\
\hline & High & 195 & 33.1 & 104 & 39.1 & & 299 & 35.0 \\
\hline
\end{tabular}

${ }^{h}: \chi^{2}$ for heterogenity

$t: \chi^{2}$ for linear trend

Table 2. Moderating effect of maturation on the bivariate association between social support, received from parents and friends, and physical activity on leisure in adolescents. São José dos Pinhais, Paraná, Brazil, 2014 (n=855).

\begin{tabular}{|c|c|c|c|c|c|c|c|c|}
\hline & \multicolumn{8}{|c|}{ Estágio maturacional } \\
\hline & \multicolumn{4}{|c|}{ Púbere } & \multicolumn{4}{|c|}{ Pós-púbere } \\
\hline & $\mathbf{n}$ & $\%$ & PR & $\mathrm{IC}_{95 \%}$ & $\mathbf{n}$ & $\%$ & $\mathbf{R P}$ & $\mathrm{IC}_{95 \%}$ \\
\hline \multicolumn{9}{|c|}{$\begin{array}{l}\text { Social support received from parents } \\
\text { Encouraged you to practice physical } \\
\text { activities }\end{array}$} \\
\hline Never & 9 & 12.2 & 1 & $<0.001 *$ & 6 & 14.6 & 1 & $0.002 *$ \\
\hline Sometimes & 66 & 17.2 & 1.42 & $0.71-2.84$ & 34 & 20.4 & 1.38 & $0.58-3.30$ \\
\hline Always & 45 & 34.4 & 2.82 & $1.39-5.78$ & 25 & 43.9 & 3.00 & 1.23-7.31 \\
\hline
\end{tabular}

with you

They practiced physical activities

$\begin{array}{lcccccccc}\text { Never } & 37 & 14.7 & 1 & \mathbf{0 . 0 0 1 *} & 25 & 20.0 & 1 & 0.237^{*} \\ \text { Sometimes } & 67 & 22.7 & \mathbf{1 . 5 4} & \mathbf{1 . 0 3 - 2 . 3 1} & 38 & 28.8 & 1.44 & 0.87-2.38 \\ \text { Always } & 16 & 38.1 & \mathbf{2 . 5 8} & \mathbf{1 . 4 4 - 4 . 6 5} & 2 & 22.2 & \mathbf{1 . 1 1} & \mathbf{2 . 6 3 - 4 . 6 9}\end{array}$




\section{Piola, T.S., Bacil, E.D.A., Watanabe, P.I., Camargo, E.M., Fermino, R., Campos, W.}

activities

They took you to practice physical

$\begin{array}{lcccccccc}\text { Never } & 32 & 13.7 & 1 & <\mathbf{0 . 0 0 1 *} & 19 & 17.9 & 1 & \mathbf{0 . 0 0 6 *}^{*} \\ \text { Sometimes } & 50 & 20.2 & 1.47 & 0.95-2.30 & 22 & 21.4 & 1.19 & 0.64-2.20 \\ \text { Always } & 38 & 35.9 & \mathbf{2 . 6 2} & \mathbf{1 . 6 3 - 4 . 2 0} & 24 & 42.1 & \mathbf{2 . 3 5} & \mathbf{1 . 2 9}-\mathbf{4 . 2 9}\end{array}$

Have watched you practice physical activities

Never
Sometimes
Always

$\begin{array}{lccccccc}29 & 10.1 & 1 & \mathbf{< 0 . 0 0 1 *} & 22 & 17.9 & 1 & \mathbf{0 . 0 3 7 *} \\ 69 & 26.4 & \mathbf{2 . 6 2} & \mathbf{1 . 7 0 - 4 . 0 4} & 37 & 29.1 & 1.63 & 0.96-2.76 \\ 22 & 55.0 & \mathbf{5 . 4 4} & \mathbf{3 . 1 2 - 9 . 4 7} & 6 & 37.5 & 2.10 & 0.85-5.17\end{array}$

They commented positively on their practice of physical activities
Never
Sometimes
Always

Talked to you about your physical activity
Never
Sometimes
Always

General social support score received from parents

$\begin{array}{lcccccccc}\text { Low } & 35 & 16.8 & 1 & 0.183^{*} & 15 & 16.1 & 1 & 0.071^{*} \\ \text { Intermediate } & 39 & 22.0 & 1.32 & 0.83-2.08 & 20 & 28.6 & 1.77 & 0.91-3.46 \\ \text { High } & 46 & 22.7 & 1.35 & 0.87-2.10 & 30 & 29.1 & 1.81 & 0.97-3.36\end{array}$

\section{Social support received from friends}

Encouraged you to practice physical activities

Never
Sometimes
Always

They practiced physical activities with you

Never
Sometimes
Always

They took you to practice physical activities

Never
Sometimes
Always

Have watched you practice physical activities

\begin{tabular}{|c|c|c|c|c|c|c|c|}
\hline Never & 21 & 8.8 & 1 & $<0.001 *$ & 17 & 17.9 & 1 \\
\hline Sometimes & 69 & 24.7 & 2.81 & $1.73-4.61$ & 33 & 26.4 & 1.4 \\
\hline Always & 30 & 43.5 & 4.94 & $2.84-8.68$ & 15 & 32.6 & 1.8 \\
\hline
\end{tabular}




\section{Sexual Maturation, social support and physical activity}

They commented positively on their practice of physical activities

$\begin{array}{lcccccccc}\text { Never } & 29 & 11.2 & 1 & <\mathbf{0 . 0 0 1 *} & 16 & 16.0 & 1 & \mathbf{0 . 0 0 5 *} \\ \text { Sometimes } & 72 & 27.2 & \mathbf{2 . 4 2} & \mathbf{1 . 5 7 - 3 . 7 2} & 31 & 25.2 & 1.58 & 0.86-2.88 \\ \text { Always } & 19 & 29.2 & \mathbf{2 . 6 0} & \mathbf{1 . 4 6 - 4 . 6 4} & 18 & 41.9 & \mathbf{2 . 6 1} & \mathbf{1 . 3 3 - 5 . 1 3}\end{array}$
activity

Talked to you about your physical

$\begin{array}{lcccccccc}\text { Never } & 15 & 8.8 & 1 & <\mathbf{0 . 0 0 1 *} & 8 & 13.1 & 1 & \mathbf{0 . 0 0 9 *} \\ \text { Sometimes } & 68 & 21.4 & \mathbf{2 . 4 3} & \mathbf{1 . 3 9 - 4 . 2 4} & 32 & 23.7 & 1.81 & 0.83-3.92 \\ \text { Always } & 37 & 37.0 & \mathbf{4 . 2 0} & \mathbf{2 . 3 0 - 7 . 6 4} & 25 & 35.7 & \mathbf{2 . 7 2} & \mathbf{1 . 2 3 - 6 . 0 4}\end{array}$

General social support score received from friends

\begin{tabular}{lcccccccc} 
Low & 20 & 11.1 & 1 & $\mathbf{0 . 0 0 9 *}$ & 10 & 21.1 & 1 & $0.165^{*}$ \\
Intermediate & 54 & 25.2 & $\mathbf{2 . 2 7}$ & $\mathbf{1 . 3 6 - 3 . 7 9}$ & 14 & 19.4 & 0.92 & $0.46-1.84$ \\
High & 46 & 23.6 & $\mathbf{2 . 1 2}$ & $\mathbf{1 . 2 6 - 3 . 5 9}$ & 32 & 30.8 & 1.46 & $0.83-2.57$ \\
\hline
\end{tabular}

* significance value for the trend test

Table 3. Moderating effect of maturation on multivariate association between social support, received from parents and friends, with physical activity in adolescents. São José dos Pinhais, Paraná, Brazil, 2014 (n=855).

\begin{tabular}{|c|c|c|c|c|}
\hline & \multicolumn{4}{|c|}{ Estágio maturacional } \\
\hline & \multicolumn{2}{|c|}{ Púbere } & \multicolumn{2}{|c|}{ Pós-púbere } \\
\hline & $\mathbf{P R}$ & $\mathrm{IC}_{95 \%}$ & $\mathbf{R P}$ & $\mathrm{IC}_{\mathbf{9 5} \%}$ \\
\hline \multicolumn{5}{|c|}{ Social support received from parents } \\
\hline \multicolumn{5}{|c|}{ Encouraged you to practice physical activities } \\
\hline Never & 1 & $0.108 *$ & 1 & $0.185^{*}$ \\
\hline Sometimes & 1.09 & $0.52-2.28$ & 1.18 & $0.46-3.05$ \\
\hline Always & 1.60 & $0.72-3.55$ & 1.74 & $0.62-4.91$ \\
\hline \multicolumn{5}{|c|}{ They practiced physical activities with you } \\
\hline Never & 1 & $0.337 *$ & 1 & $0.400 *$ \\
\hline Sometimes & 0.90 & $0.55-1.47$ & 0.99 & $0.55-1.79$ \\
\hline Always & 0.65 & $0.30-1.45$ & 0.37 & $0.08-1.70$ \\
\hline \multicolumn{5}{|c|}{ They took you to practice physical activities } \\
\hline Never & 1 & $0.266^{*}$ & 1 & $0.112^{*}$ \\
\hline Sometimes & 1.09 & $0.67-1.79$ & 0.98 & $0.49-1.95$ \\
\hline Always & 1.37 & $0.79-2.40$ & 1.82 & $0.86-3.86$ \\
\hline \multicolumn{5}{|c|}{ Have watched you practice physical activities } \\
\hline Never & 1 & $<0.001 *$ & 1 & $0.721 *$ \\
\hline Sometimes & 2.51 & $1.42-4.44$ & 1.12 & $0.57-2.26$ \\
\hline Always & 4.60 & 2.10-10.10 & 1.19 & $0.39-3.65$ \\
\hline \multicolumn{5}{|c|}{$\begin{array}{l}\text { They commented positively on their practice of } \\
\text { physical activities }\end{array}$} \\
\hline Never & 1 & $0.910 *$ & 1 & $0.048 *$ \\
\hline Sometimes & 0.70 & $0.40-1.21$ & 1.73 & $0.81-3.72$ \\
\hline Always & 0.93 & $0.46-1.85$ & 2.60 & 1.01-6.71 \\
\hline \multicolumn{5}{|c|}{ Talked to you about your physical activity } \\
\hline Never & 1 & $0.508 *$ & 1 & $0.246^{*}$ \\
\hline
\end{tabular}




\section{Piola, T.S., Bacil, E.D.A., Watanabe, P.I., Camargo, E.M., Fermino, R., Campos, W.}

$\begin{array}{llllr}\text { Sometimes } & 1.28 & 0.77-2.15 & 0.68 & 0.32-1.45 \\ \text { Always } & 1.24 & 0.62-2.45 & 0.55 & 0.20-1.49\end{array}$

General social support score received from parents $* * *$

$\begin{array}{lcccc}\text { Low } & 1 & 0.467^{*} & 1 & 0.092^{*} \\ \text { Intermediate } & 1.23 & 0.78-1.96 & 1.79 & 0.91-3.51 \\ \text { High } & 1.19 & 0.76-1.86 & 1.72 & 0.91-3.24\end{array}$

\section{Social support received from friends}

Encouraged you to practice physical activities

Never

Sometimes

Always

They practiced physical activities with you

Never

Sometimes

Always

They took you to practice physical activities
Never
Sometimes

Always

Have watched you practice physical activities
Never
Sometimes
Always

They commented positively on their practice of physical activities
Never
Sometimes

Always

Talked to you about your physical activity

Never
Sometimes
Always

Always

General social support score received from parents

$\begin{array}{lcc}\text { Low } & 1 & \mathbf{0 . 0 3 7 *} \\ \text { Intermediate } & \mathbf{2 . 1 3} & \mathbf{1 . 2 8 - 3 . 5 8} \\ \text { High } & \mathbf{1 . 9 1} & \mathbf{1 . 1 1 - 3 . 2 8}\end{array}$

\section{1 \\ 0.84}

0.86

$0.825 *$

0.65

$0.37-1.12$

$0.47-1.73$

$0.33-2.13$

0.90

$0.378 *$

1

0.949 *

$0.86 \quad 0.40-1.88$

0.51-3.02

1.19

1.09

$0.45-3.15$

1.25

$0.509 *$

0.65-3.65

$0.59-4.23$

\section{1}

2.86

3.35

0.153 *

1.54

1.58

0.049*

0.99-3.96

1

0.73

0.75

$0.612 *$

1.99

1.01-5.76

0.392 *

$0.74-2.22$

1

$0.215^{*}$

1.28

$0.40-1.43$

1.21

1.90

$0.53-2.77$

0.66

0.077*

0.81-3.12

$0.93-4.68$

* significance value for the trend test 


\section{Sexual Maturation, social support and physical activity}

\section{DISCUSSION}

This is the first study that analyzed the moderating effect of maturation on the association between social support received from parents and friends with leisure physical activity of adolescents of both sexes. Evidence pointed to a consistent positive association between social support and physical activity, however, they did not analyze the maturation effect (Beets et al., 2010; Corbí, Moreno-Murcia, \& Gea-Escámez, 2018; Costa, Pureza, \& Mielke, 2017; Laird et al., 2016; G. Mendonça et al., 2014; Gerfeson Mendonça \& Farias Júnior, 2015; Tebar et al., 2018; Todisco et al., 2017). The methodology used allowed the evaluation of these parameters in a representative sample of adolescents enrolled in the public-school system, which is one of the study's strengths.

The results reinforce the pre-established hypothesis by pointing out the moderating effect of maturation on the association between social support and adolescent physical activity. The presence of parents, when attending their children's activities, was positively associated with the physical activity of pubertal adolescents, while positive reinforcement was positively associated with the physical activity of postpubertal adolescents. The presence of friends, when attending activities, and the highest overall social support score were positively associated with the physical activity of pubescent adolescents.

The absence of similar studies limits, in part, the adequate comparison and discussion of the results of the present study (Costa et al., 2017; Gerfeson Mendonça \& Farias Júnior, 2015; Tebar et al., 2018; Todisco et al., 2017). The presence of the parents, when attending "sometimes" (PR: 2.51; 95\% CI: 1.424.44 ) or "always" (PR: 4.60; 95\% CI: 2.10-10.10) the activities of their children showed a significant association with the physical activity of pubescent adolescents, similar with Torre-Cruz et al study (2019). Few studies have analyzed the association between this type of social support and adolescents' physical activity according to age (Marques, González Valeiro, Martins, Fernández-Villarino, \& Carreiro da Costa, 2017; G. Mendonça et al., 2014). For example, Mendonça and Farias Jr (Gerfeson Mendonça \& Farias Júnior, 2015) did not find a moderating effect on the age group ("14-16 years" vs. "17-19 years") in the association between parental support when they see their children performing activities with the level of physical activity of adolescents from João PessoaParaíba, Brazil.

Most social support types exploited in present study did not show a significant association with physical activity, indicating that perhaps physical education teachers support may also be considered as favorable to the practice of physical activities of adolescents (Trigueros-Ramos, Gómez, Aguilar-Parra, \& LeónEstrada, 2019).

Some limitations should be considered for the proper interpretation and extrapolation of the results of this study. The sample is representative of adolescents aged 14-18, students of the public-school system, in the urban area of a medium-sized municipality in the southern region of the country. Therefore, the external validity and inference of the results are limited for adolescents of other age groups, students from private schools or from rural areas, from large capitals or regions of the country with different socioeconomic conditions. Parental social support was assessed globally, which made it impossible to analyze specific sources such as the father or mother. Similarly, social support was not assessed according to the sex of the friends (support relationship girl-girl, boy-boy, etc.). Finally, the cross-sectional design does not allow establishing the causal relationship between the variables. However, the procedures used to select the sample made it possible to reduce the selection bias, the main confounding factors were controlled and the sample size was sufficient to detect the effects in the multivariate analysis, which increases the internal validity of the study.

\section{CONCLUSION}

Maturation has a moderating effect on the association between social support and physical activity in adolescents. Regarding the social support of the parents, the fact that they attended the activities of the children was positively associated with the physical activity of pubertal adolescents, while the positive reinforcement was associated with the outcome in postpubertal adolescents. When friends attend activities and provide greater overall support, they are thus positively associated with the physical activities of pubescent adolescents.

These results are important so that health professionals can advise parents about their behavior 


\section{Piola, T.S., Bacil, E.D.A., Watanabe, P.I., Camargo, E.M., Fermino, R., Campos, W.}

and actions, as well as actions towards adolescents 'friends, which can stimulate adolescents' involvement, according to maturation, in activities physical and sports activities of greater intensity in leisure. Future experimental studies could analyze the effect that different types and sources of social support (father, mother, siblings, same-sex and opposite-sex friends) could provide on behavior in specific modalities / intensities of physical activity in adolescents.

\section{REFERENCIAS (APA 6 ${ }^{\text {a }}$ EDICION)}

1. ABEP. (2013). Critério de Classificação Econômica Brasil. Associação Brasileira de Empresas de Pesquisa, 2013.

2. Adams, M. A., Johnson, W. D., \& Tudor-Locke, C. (2013). Steps/day translation of the moderateto-vigorous physical activity guideline for children and adolescents. Int $\mathrm{J}$ Bev Nutrit Phys Activity, 10(1), 49.

3. Bacil, E. D., Mazzardo Junior, O., Rech, C. R., Legnani, R. F., \& Campos, W. (2015). Physical activity and biological maturation: a systematic review. Rev Paul Pediatr, 33(1), 114-121. doi:10.1016/j.rpped.2014.11.003

4. Barbosa Filho, V. C., Campos, W., Bozza, R., \& Lopes, A. S. (2012). The prevalence and correlates of behavioral risk factors for cardiovascular health among Southern Brazil adolescents: a crosssectional study. BMC Pediatrics, 12(130), 12. doi:10.1186/1471-2431-12-130

5. Barros, A. J., \& Hirakata, V. N. (2003). Alternatives for logistic regression in crosssectional studies: an empirical comparison of models that directly estimate the prevalence ratio. BMC medical research methodology, 3(1), 21.

6. Bauman, A. E., Reis, R. S., Sallis, J. F., Wells, J. C., Loos, R. J., \& Martin, B. W. (2012). Correlates of physical activity: why are some people physically active and others not? Lancet,
$380(9838), \quad 258-271 . \quad$ doi:10.1016/s0140-
$6736(12) 60735-1$

7. Bauman, A. E., Sallis, J. F., Dzewaltowski, D. A., \& Owen, N. (2002). Toward a better understanding of the influences on physical activity: the role of determinants, correlates, causal variables, mediators, moderators, and confounders. Am J Prev Med, 23(2 Suppl), 5-14.

8. Beets, M. W., Cardinal, B. J., \& Alderman, B. L. (2010). Parental social support and the physical activity-related behaviors of youth: a review. Health Educ Behav, 37(5), 621-644. doi:10.1177/1090198110363884

9. Conde, W. L., \& Monteiro, C. A. (2006). Valores críticos do índice de massa corporal para classificação do estado nutricional de crianças e adolescentes brasileiros. J Pediatr, 82, 266-272.

10. Corbí, M., Moreno-Murcia, J. A., \& GeaEscámez, A. (2018). Predicción de la percepción de actividad física de los hijos a partir de la creencia de habilidad de los padres. Cuadernos de Psicología del Deporte, 18(3), 1-11.

11. Costa, D., Pureza, D., \& Mielke, G. (2017). Prevalência de inatividade física e apoio social dos pais em adolescentes de Macapá-Amapá. Rev Bras Ativ Fis Saúde, 22(6), 533-539.

12. Davison, K. K., Werder, J. L., Trost, S. G., Baker, B. L., \& Birch, L. L. (2007). Why are early maturing girls less active? Links between pubertal development, psychological well-being, and physical activity among girls at ages 11 and 13 . Soc Sci Med, 64(12), 2391-2404. doi:http://dx.doi.org/10.1016/j.socscimed.2007.0 2.033

13. De La Torre-Cruz, M. J., Ruiz-Ariza, A., SuarezManzano, S., \& Martinez-Lopez, E. (2019). Perceived parental support and adolescents' 


\section{Sexual Maturation, social support and physical activity}

motivation toward physical activity. Journal of Sport Psychology, 28(1), 51-61.

14. Dumith, S. C., Gigante, D. P., Domingues, M. R., \& Kohl III, H. W. (2011). Physical activity change during adolescence: a systematic review and a pooled analysis. Int J Epidemiol, 40(3), 685-698. doi:10.1093/ije/dyq272

15. Farias Júnior, J. C., Lopes, A. S., Mota, J., Santos, M. P., Ribeiro, J. C., \& Hallal, P. C. (2012). Validade e reprodutibilidade de um questionário para medida de atividade física em adolescentes: uma adaptação do Self-Administered Physical Activity Checklist. Rev Bras Epidemiol, 15(1), 198-210.

16. Farias Júnior, J. C., Lopes, A. S., Reis, R. S., Nascimento, J. V., Borgatto, A. F., \& Hallal, P. C. (2011). Development and validation of a questionnaire measuring factors associated with physical activity in adolescents. Rev Bras Saude Mater Infant, 11(3), 301-312.

17. Ferreira, R. W., Varela, A. R., Monteiro, L. Z., Häfele, C. A., Santos, S. J. d., Wendt, A., \& Silva, I. C. M. (2018). Desigualdades sociodemográficas na prática de atividade física de lazer e deslocamento ativo para a escola em adolescentes: Pesquisa Nacional de Saúde do Escolar (PeNSE 2009, 2012 e 2015). Cad. Saúde Pública, 34.

18. Glanz, K., Rimer, B. K., \& Viswanath, K. (2008). Health Behavior and Health Education: Theory, Research, and Practice (4th ed ed.): Wiley.

19. Hills, A. P., \& Byrne, N. M. (2010). An overview of physical growth and maturation. In Cytokines, Growth Mediators and Physical Activity in Children during Puberty (Vol. 55, pp. 1-13): Karger Publishers.

20. Jackson, L., Cumming, S. P., Drenowatz, C., Standage, M., Sherar, L. B., \& Malina, R. M.
(2013). Biological maturation and physical activity in adolescent British females: The roles of physical self-concept and perceived parental support. Psychol Exerc Sci, 14(4), 447-454.

21. Laird, Y., Fawkner, S., Kelly, P., McNamee, L., \& Niven, A. (2016). The role of social support on physical activity behaviour in adolescent girls: a systematic review and meta-analysis. Int J Behav Nutr Phys Act, 13, 79. doi:10.1186/s12966-0160405-7

22. Lloyd, R. S., Oliver, J. L., Faigenbaum, A. D., Myer, G. D., \& Croix, M. B. D. S. (2014). Chronological age vs. biological maturation: implications for exercise programming in youth. $\mathrm{J}$ Strength Cond Res, 28(5), 1454-1464.

23. Luiz, R. R., \& Magnanini, M. M. F. (2000). A lógica da determinação do tamanho da amostra em investigações epidemiológicas. Cad Saude Publica, 8(2), 9-28.

24. Malina, R. M., Rogol, A. D., Cumming, S. P., Silva, M. J. C., \& Figueiredo, A. J. (2015). Biological maturation of youth athletes: assessment and implications. Br J Sports Med, 49(13), 852-859.

25. Marques, A., González Valeiro, M., Martins, J., Fernández-Villarino, M. A., \& Carreiro da Costa, F. (2017). Relación entre la actividad física de los adolescentes y la de madres/padres. Journal of Sport Psychology, 26(1), 0145-0156.

26. Mendonça, G., Cheng, L. A., Melo, E. N., \& Farias Junior, J. C. (2014). Physical activity and social support in adolescents: a systematic review. Health Educ Res, 29(5), 822-839. doi:10.1093/her/cyu017

27. Mendonça, G., \& Farias Júnior, J. C. (2015). Physical activity and social support in adolescents: analysis of different types and 


\section{Piola, T.S., Bacil, E.D.A., Watanabe, P.I., Camargo, E.M., Fermino, R., Campos, W.}

sources of social support. J Sports Sci, 33(18), 1942-1951.

28. Organization, W. H. (2010). Global recommendations on physical activity for health.

29. Piola, T. S., Bacil, E. D. A., Silva, M. P., Pacifico, A. B., \& Campos, W. (2018). Associação entre apoio social e nível de atividade física em adolescentes. Rev Bras Ativ Fis Saúde, 23, 2131 .

30. Prado, C. V., Lima, A. V., Fermino, R. C., Anez, C. R. R., \& Reis, R. S. (2014). Social support and physical activity in adolescents from public schools: the importance of family and friends. Cad. Saúde Pública, 30(4), 827-838. doi:10.1590/0102-311x00014313

31. Sallis, J. F., Bull, F., Guthold, R., Heath, G. W., Inoue, S., Kelly, P., . . . Hallal, P. C. (2016). Progress in physical activity over the Olympic quadrennium. Lancet, 388(10051), 1325-1336. doi:10.1016/S0140-6736(16)30581-5

32. Seabra, A. F., Mendonca, D. M., Thomis, M. A., Anjos, L. A., \& Maia, J. A. (2008). Biological and socio-cultural determinants of physical activity in adolescents. Cad. Saúde Pública, 24(4), 721-736.

33. SEED-PR. (2014). Consulta Escolas. Retrieved fromhttp://www.consultaescolas.pr.gov.br/consul taescolas/f/fcls/municipio/consultasEnsino.xhtml ?cid $=1$

34. Sherar, L. B., Cumming, S. P., Eisenmann, J. C., Baxter-Jones, A. D., \& Malina, R. M. (2010). Adolescent biological maturity and physical activity: biology meets behavior. Pediatr Exerc Sci, 22(3), 332-349.

35. Sherar, L. B., Gyurcsik, N. C., Humbert, M. L., Dyck, R. F., Fowler-Kerry, S., \& Baxter-Jones, A.
D. (2009). Activity and barriers in girls (8-16 yr) based on grade and maturity status. Med Sci Sports $\quad$ Exerc, 41(1), 87-95. doi:10.1249/MSS.0b013e31818457e6

36. Tebar, W. R., Oliveira, C., Gil, F., Saraiva, B. T., Suetake, V. Y., Scarabottolo, C. C., . . . Christofaro, D. G. (2018). Physical activity of parents and of their children: a systematic review of Brazilian sample studies-Report Card Brazil. Rev Bras Cineantropom Desempenho Hum, 20(4), 532-542.

37. Todisco, W., Guilherme, F., Fernandes, C., Santos, S., Ravagnani, R., Barbosa, W., . . . Rinaldi, W. (2017). Nível de atividade física e apoio social dos pais e amigos em escolares da rede pública. Rev Bras Ati Fis Saúde, 22(5), 457463.

38. Trigueros-Ramos, R., Gómez, N. N., AguilarParra, J. M., \& León-Estrada, I. (2019). Influencia del docente de Educación Física sobre la confianza, diversión, la motivación y la intención de ser físicamente activo en la adolescencia. Cuadernos de Psicologia del Deporte, 19(1), 222232.

39. Van Der Horst, K., Paw, M. J., Twisk, J. W., \& Van Mechelen, W. (2007). A brief review on correlates of physical activity and sedentariness in youth. Med Sci Sports Exerc, 39(8), 1241-1250. doi:10.1249/mss.0b013e318059bf35 